\title{
De Lange Syndrome: Report of a Case with an Unusual Karyotype
}

\author{
J. M. BERG*, G. F. SMITH, M. A. C. RIDLER, B. D. McCREARY†, JANET A. FAUNCH, \\ FAITH N. FARNHAM, and MARY L. ALLEN
}

\section{From the Kennedy-Galton Centre, Harperbury Hospital, near St. Albans, Hertfordshire}

The eponym de Lange syndrome is now frequently applied to that combination of clinical peculiarities, the first recognition of which, as an entity, is usually attributed to the Dutch paediatrician, Cornelia de Lange (1933). The syndrome received relatively little attention until the past few years, since when substantially more examples have been recorded than in the three decades following de Lange's initial report. About 150 cases have now been published, from many countries, making the nomenclature 'typus Amstelodamensis', originally suggested by de Lange, somewhat misleading.

A wide range of clinical features has been noted in individuals regarded as examples of the de Lange syndrome. Comprehensive accounts of these features include those of Jervis and Stimson (1963) and Ptacek, Opitz, Smith, Gerritsen, and Waisman (1963). Among the most characteristic findings are retarded mental and physical development, generalized hirsutism, peculiar facies (including confluent eyebrows, long eyelashes, anteverted nostrils, and thin lips), and malformations of the limbs, ranging from mild syndactyly to gross micromelia. Dermatoglyphic patterns may be a useful diagnostic aid (Smith, 1966).

The aetiology of the syndrome remains obscure. In recent years, one of the approaches to this question has been the examination of the chromosomes of affected persons. In the large majority of these cases, the karyotype has been described as normal. In some instances, however, unusual chromosomal appearances, differing from case to case, have been noted. We record below a further example of the de Lange syndrome associated with an unusual karyotype, and briefly review the re-

Received February 23, 1967.

* In receipt of a grant from the Medical Research Council.

t In receipt of a travelling fellowship from the Ontario Mental Health Foundation. ported occurrence of chromosomal variants in this condition.

\section{Case Report}

The propositus was born spontaneously, following an apparently normal pregnancy of about 8 months' duration, to healthy West Indian parents. His birthweight was $2240 \mathrm{~g}$. (4 lb. $13 \mathrm{oz}$.). At the time of the birth, the mother was aged 35 years and the father 26 years. A maternal half-brother, 9 years older than the propositus, and a full-brother, 3 years older, are both normal. The mother has had no other pregnancies. There is no family history of consanguinity nor of any clinical features suggestive of de Lange syndrome.

The main characteristics noted in infancy were malformation of the right hand, peculiar facies, and poor physical and mental progress. At the age of 6 years, the propositus was seen at this Centre when a diagnosis of de Lange syndrome was made. The findings were as follows.

Clinical Examination. He showed severe mental retardation (estimated $\mathrm{IQ}=25$ ) and reduction in stature $(94.5 \mathrm{~cm}$.) and weight $(12.4 \mathrm{~kg}$.). The head was small and rounded (norms in brackets): circumference $=$ $450 \mathrm{~mm}$. (520 mm.); breadth $=129 \mathrm{~mm}$. $(140 \mathrm{~mm}$.); length $=148 \mathrm{~mm}$. (177 mm.); cephalic index $=0.87$ $(0.79)$. The hair-line was relatively low and there was no dilatation of the temporal veins. The appearance of the face is shown in Fig. 1. The eyebrows were confluent and the eyelashes long, but no ocular abnormalities were noted. The root of the nose was broad and the nostrils were flared and anteverted. The distance between the nose and upper lip was relatively long, with slight hirsutism in this region. The lips were thin, compared with those of the parents and sibs, and there was no peri-oral cyanosis. The teeth were well formed, and the tongue, palate, and fauces were normal. There was no speech but the sounds emitted were normally pitched. The ears were rather small and possibly somewhat low-set. The symphysis menti was prominent though there was moderate micrognathia. The neck seemed to be of normal size. No clinical abnormalities of the heart, lungs, or abdomen were found. 


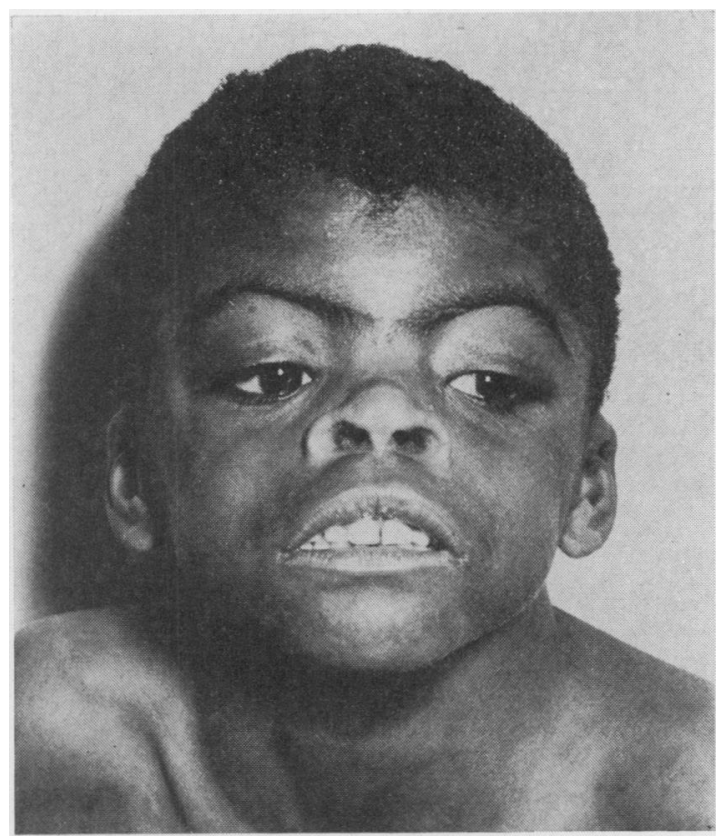

FIG. 1. Facial appearance of propositus, aged 6 years.

The testes were undescended. The back was hirsute, particularly in the midline. There was limitation of extension at the elbow joints and hirsutism of the forearms. As indicated in Fig. 2 and 3, the right hand was grossly malformed and the left hand showed a tendency to syndactyly of the middle three fingers and a short fifth finger without clinodactyly. On both feet, all the
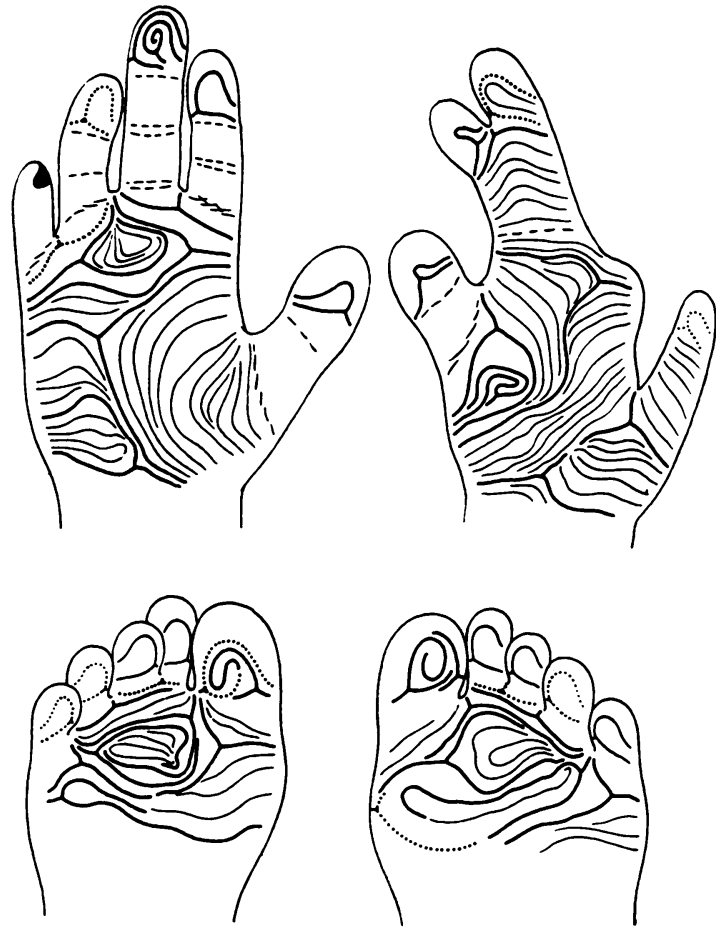

Fig. 3. Dermatoglyphic main lines on hands and feet.

toes were small and short, the middle three also showing a tendency to syndactyly. No gross neurological abnormalities were detected and there was no evidence of epilepsy.

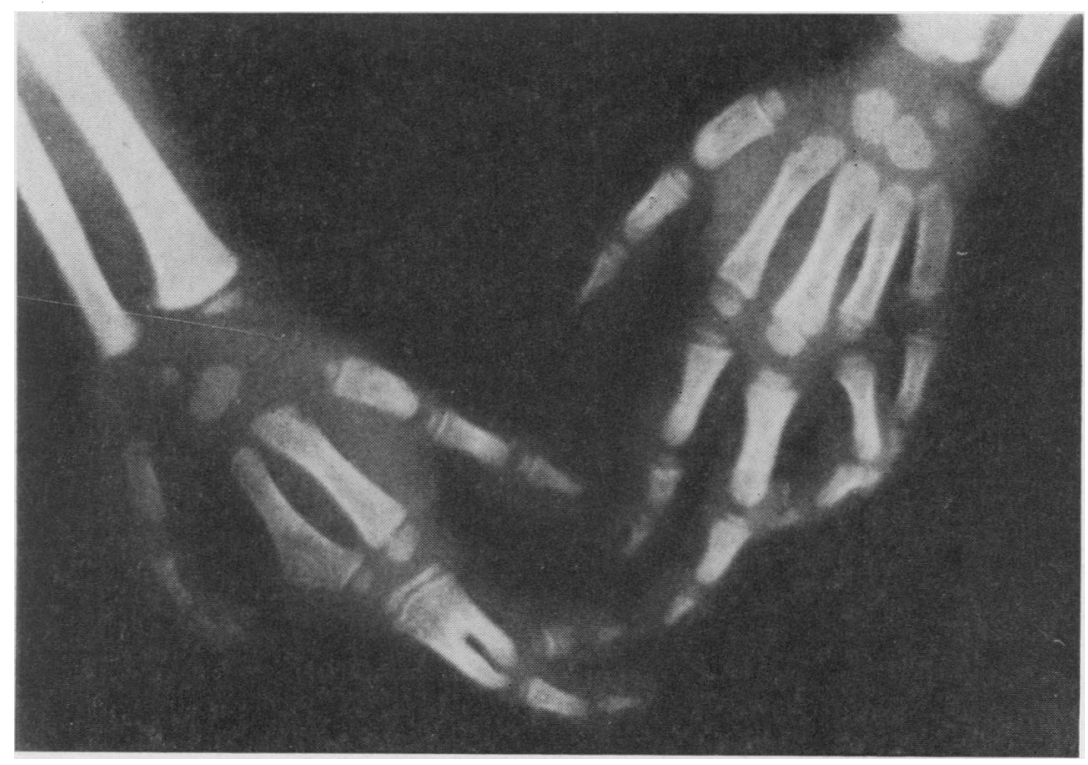

FIG. 2. $X$-ray picture of hands of propositus. 
TABLE I

DERMATOGLYPHIC PATTERNS ON HANDS AND FEET OF PROPOSITUS AND HIS RELATIVES

\begin{tabular}{|c|c|c|c|c|c|c|c|c|c|c|}
\hline \multirow{4}{*}{ Subject } & \multicolumn{6}{|c|}{ Hands } & \multicolumn{4}{|c|}{ Feet } \\
\hline & \multicolumn{2}{|c|}{ Finger-tip Patterns } & \multicolumn{2}{|c|}{$\begin{array}{c}\text { Maximal } \\
\text { atd Angles }\end{array}$} & \multicolumn{2}{|c|}{$\begin{array}{l}\text { Thenar } \\
\text { pattern }\end{array}$} & \multicolumn{2}{|c|}{ Toe-tip Patterns } & \multicolumn{2}{|c|}{$\begin{array}{c}\text { Hallucal } \\
\text { Pattern }\end{array}$} \\
\hline & Left & Right & I eft & & & & Left & Right & eft & Right \\
\hline & V IV III II I & I II IIIIV V & Lert & & & Sil & V IV III II I & I II IIIIV $\mathrm{V}$ & LeIt & Nghl \\
\hline $\begin{array}{l}\text { Propositus } \\
\text { Father } \\
\text { Mother } \\
\text { Brother } \\
\text { Half-brother }\end{array}$ & $\begin{array}{lllll} & \mathbf{R} & \mathbb{W} & \mathbf{R} & \mathbf{U} \\
\mathbf{U} & \mathbf{W} & \mathbb{W} & \mathbb{W} & \mathbb{W} \\
\mathbf{U} & \mathbf{U} & \mathbf{U} & \mathbf{U} & \mathbf{W} \\
\mathbb{W} & \mathbb{W} & \mathbb{W} & \mathbb{W} & \mathbb{W} \\
\mathbf{U} & \mathbf{U} & \mathbf{U} & \mathbf{R} & \mathbf{U}\end{array}$ & \begin{tabular}{|ccccc}
$\mathbf{U}$ & $\mathbf{U}$ & $\mathbf{U}$ & $*$ & $\mathbf{U}$ \\
$\mathbf{W}$ & $\mathbf{W}$ & $\mathbf{W}$ & $\mathbf{W}$ & $\mathbf{U}$ \\
$\mathbf{U}$ & $\mathbf{U}$ & $\mathbf{U}$ & $\mathbf{U}$ & $\mathbf{U}$ \\
$\mathbf{W}$ & $\mathbf{W}$ & $\mathbf{W}$ & $\mathbf{W}$ & $\mathbb{W}$ \\
$\mathbf{W}$ & $\mathbf{W}$ & $\mathbf{W}$ & $\mathbf{W}$ & $\mathbf{U}$
\end{tabular} & $\begin{array}{l}67^{\circ} \\
35^{\circ} \\
40^{\circ} \\
41^{\circ} \\
39^{\circ}\end{array}$ & $\begin{array}{l}{ }^{*} \\
34^{\circ} \\
35^{\circ} \\
41^{\circ} \\
40^{\circ}\end{array}$ & $\begin{array}{l}0 \\
0 \\
0 \\
+ \\
0\end{array}$ & $\begin{array}{l}* \\
0 \\
0 \\
0 \\
0\end{array}$ & 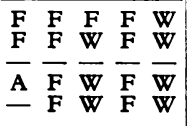 & $\begin{array}{lllll}W & F & F & F & F \\
F & F & W & F & F \\
W & F & \frac{F}{W} & F & F \\
F & F & F & F & F\end{array}$ & $\begin{array}{l}\text { Op } \\
\text { W } \\
\mathrm{D} \\
\mathrm{T} \\
\mathrm{T}\end{array}$ & $\begin{array}{l}\mathrm{F} \\
\mathrm{D} \\
\mathrm{D} \\
\mathrm{T} \\
\mathbf{W}\end{array}$ \\
\hline
\end{tabular}

$W=$ whorl; $A=\operatorname{arch} ; \mathbf{R}=$ radial loop; $U=$ ulnar loop; $F=$ fibular loop; $T=$ tibial loop; $D=$ distal loop; Op $=$ open field.

$*=$ malformed hand with missing finger; $0=$ absence of pattern; $-=$ missing or undetectable; $+=$ present.

TABLE II

CHROMOSOMAL EXAMINATION OF PROPOSITUS AND HIS RELATIVES

\begin{tabular}{|c|c|c|c|c|c|c|c|c|}
\hline \multirow[t]{2}{*}{ Subject } & \multirow[t]{2}{*}{ Tissue } & \multirow{2}{*}{$\begin{array}{l}\text { Duration } \\
\text { of } \\
\text { Culture }\end{array}$} & \multirow{2}{*}{$\begin{array}{l}\text { No. of } \\
\text { Cells } \\
\text { Analysed }\end{array}$} & \multicolumn{3}{|c|}{$\begin{array}{l}\text { Chromosome } \\
\text { Counts }\end{array}$} & \multirow{2}{*}{$\begin{array}{l}\text { Sex } \\
\text { Chromosomes }\end{array}$} & \multirow[t]{2}{*}{ Main Findings* } \\
\hline & & & & 45 & 46 & 47 & & \\
\hline \multirow{2}{*}{ Propositus } & $\int$ Leucocytes & & & 0 & 30 & 0 & $\mathbf{X Y}$ & Metacentric 6-12 group chromosome (thought \\
\hline & Fibroblasts & 29 dy. & 41 & 1 & 38 & 2 & $\mathbf{X Y}$ & $\begin{array}{l}21-22 \text { group chromosome with prominent } \\
\text { satellites in all cells from leucocyte culture } \\
\text { and } 50 \% \text { of cells from fibroblast culture }\end{array}$ \\
\hline Father & Leucocytes & $72 \mathrm{hr}$. & 30 & 0 & 30 & 0 & $\mathbf{X Y}$ & $\begin{array}{l}\text { Metacentric 6-12 group chromosome (thought } \\
\text { to be No. 9) in all cells; } 21-22 \text { group } \\
\text { chromosome with prominent satellites in } \\
\text { all cells }\end{array}$ \\
\hline Mother & Leucocytes & $72 \mathrm{hr}$. & 30 & 1 & 29 & 0 & $x x$ & $\begin{array}{l}\text { Apparently normal karyotype without findings } \\
\text { noted in propositus and father }\end{array}$ \\
\hline Brother & Leucocytes & $72 \mathrm{hr}$. & 30 & 0 & 30 & 0 & $\mathbf{X Y}$ & $\begin{array}{l}\text { Apparently normal karyotype without findings } \\
\text { noted in propositus and father }\end{array}$ \\
\hline Half-brother & Leucocytes & $72 \mathrm{hr}$. & 46 & 0 & 46 & 0 & $\mathbf{X Y}$ & $\begin{array}{l}\text { Apparently normal karyotype without findings } \\
\text { noted in propositus and his father }\end{array}$ \\
\hline
\end{tabular}

* In addition, inconstant dimorphism was noted in some autosomes of all subjects.

Dermatoglyphs. The dermatoglyphic main lines on the hands and feet of the propositus are shown in Fig. 3 , and these patterns, together with those of near relatives, are summarized in Table I. Features on the left hand of the propositus, often found in de Lange syndrome, are a radial loop on the second digit, a disturbance of the triradii $a$ and $b$ at the base of the fingers, and a wide atd angle $\left(67^{\circ}\right)$; on the malformed right hand, patterns are grossly distorted, but the thenar configuration is sometimes seen in the syndrome. The patterns in the relatives examined, including the father, are dissimilar from those of the propositus and not suggestive of de Lange syndrome.

Cytology. Metaphase chromosome of the propositus, his parents, and sibs were examined in air-dried preparations from leucocyte cultures. Chromosomes were also examined in a fibroblast culture derived from a skin biopsy of the left shoulder of the propositus. The results are summarized in Table II. All subjects showed a modal number of 46 chromosomes. An atypical medium-sized metacentric chromosome in the 6-12 group, which was consistently present in preparations from the propositus and his father, is illustrated in Fig. 4 and 5. In many cells this chromosome showed a distinct paracentric secondary constriction, as did another 6-12 group chromosome which was submetacentric and of similar length to the metacentric one. The relative length, arm ratio, and presence of a paracentric long-arm secondary constriction in this submetacentric chromosome indicated that it was probably a No. 9, with the metacentric chromosome as its most likely homologue. (Such a constriction has been observed most frequently in a No. 9 chromosome (FergusonSmith, Ferguson-Smith, Ellis, and Dickson, 1962; Palmer and Funderburk, 1965).)

Other Investigations. Radiological examination (Dr. R. W. McNabb) of the skull, chest, and feet showed no abnormalities. An $x$-ray film of the wrists revealed a bone age of approximately 2 years 8 months. Fig. 2 illustrates the osseous malformation of the right hand. 


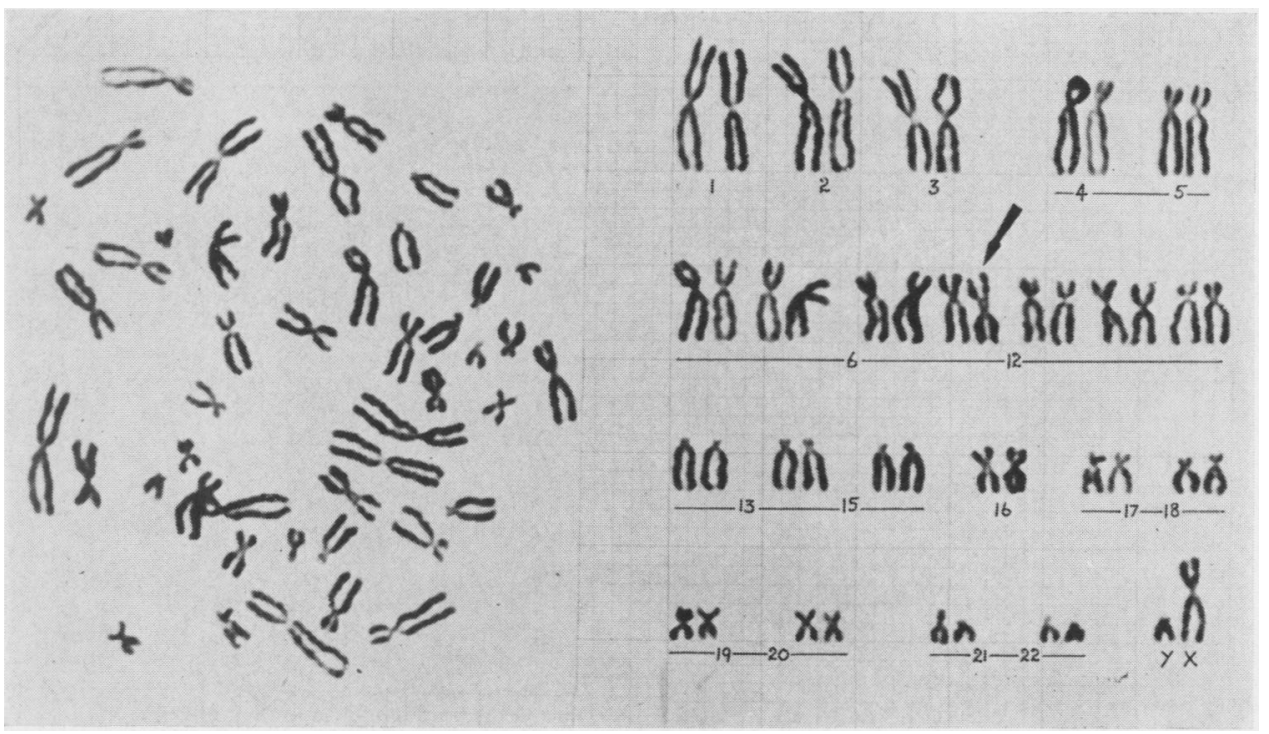

Fig. 4. Metaphase chromosomes from cultured leucocyte of propositus, with analysis, showing aberrant metacentric chromosome (arrowed).

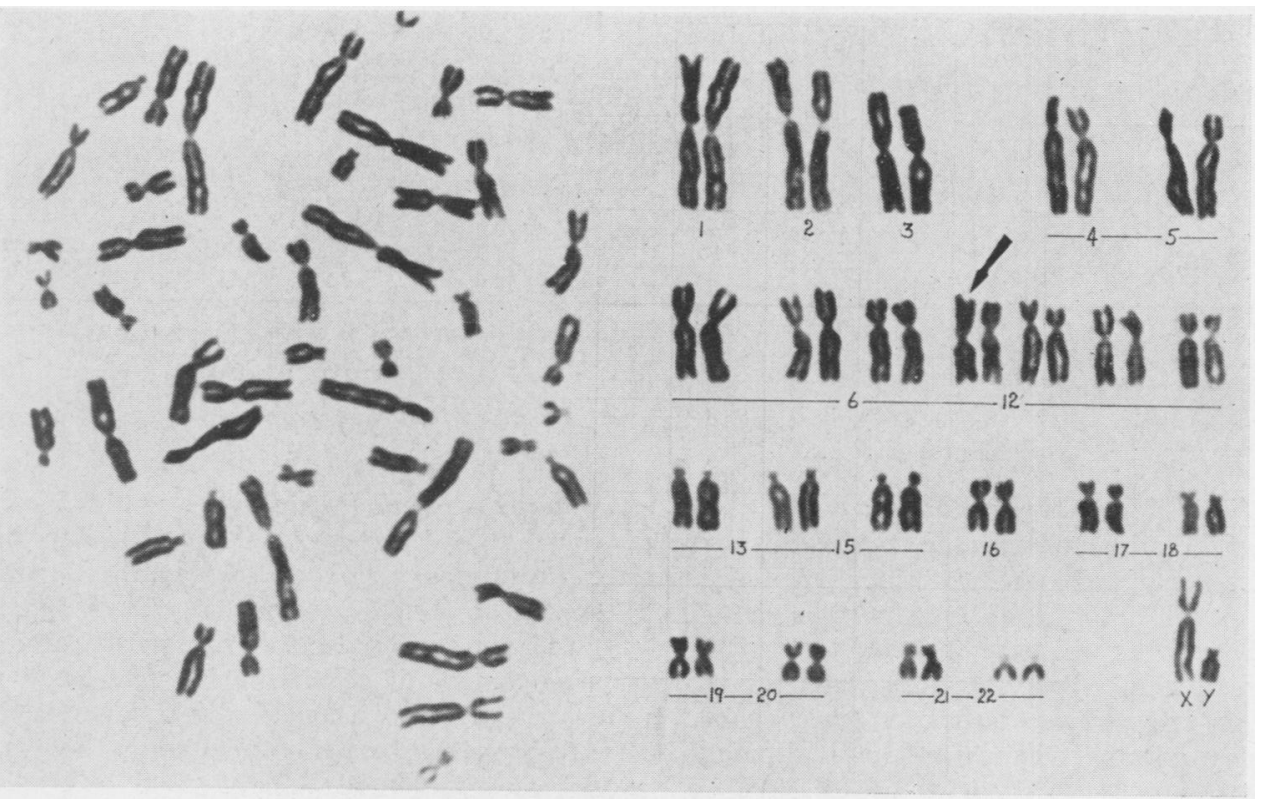
FIG. 5. Metaphase chromosomes from cultured leucocyte of father of propositus, with analysis, showing aberrant metacentric chromo-
some (arrowed).

Haematological tests gave the following results: Hb 11.7 g./100 ml.; WBC 11,500/c.mm., with slight increase of monocytes; Arneth count (mean lobes per cell) 2.39 (norm for this laboratory $2 \cdot 7$ (S.D. 0.18)).

The serum calcium, inorganic phosphate, and alkaline phosphatase were, respectively, $9.8 \mathrm{mg} ., 4.0 \mathrm{mg}$., and $13 \mathrm{~K}$.A. units $/ 100 \mathrm{ml}$.
The urine contained a slight trace of protein, was free from ketones, reducing substances, and mucopolysaccharides, and had a normal keto-acid content. Urine calcium was absent on one occasion and much reduced on another. Nothing abnormal was detected on amino acid chromatography. 
TABLE III

CHROMOSOMAL ANOMALIES DESCRIBED IN REPORTED CASES OF DE LANGE SYNDROME*

\begin{tabular}{|c|c|c|c|c|c|c|}
\hline Authors & $\begin{array}{l}\text { Author's } \\
\text { Reference } \\
\text { to Case No. }\end{array}$ & Sex & $\begin{array}{l}\text { Age at } \\
\text { Exami- } \\
\text { nation } \\
(\text { yr. })\end{array}$ & $\begin{array}{c}\text { Tissue } \\
\text { Examined } \\
\text { (no. of cells in } \\
\text { brackets) }\end{array}$ & Chromosomal Anomaly & $\begin{array}{c}\text { Chromosomal Findings in } \\
\text { Relatives }\end{array}$ \\
\hline $\begin{array}{l}\text { Geudeke, Bijlsma, and } \\
\text { de Bruijne (1963) } \\
\text { (Case referred to by } \\
\text { Ford, 1964) }\end{array}$ & No. 4 & $\mathbf{M}$ & Infancy & $\begin{array}{l}\text { Leucocytes (100) } \\
\text { Fibroblasts (50) }\end{array}$ & $\begin{array}{l}4-5 / 21-22 \text { translocation in } \\
\text { most cells from both } \\
\text { tissues }\end{array}$ & Parents-normal karyotypes \\
\hline $\begin{array}{l}\text { Jervis and Stimson } \\
\text { (1963) }\end{array}$ & $\begin{array}{l}\text { No. } 1 \\
\text { No. } 2 \\
\text { No. } 3 \\
\text { No. } 4\end{array}$ & $\begin{array}{l}\mathbf{M} \\
\mathbf{M} \\
\mathbf{M} \\
\mathbf{M}\end{array}$ & $\begin{array}{l}6 \\
6 \\
1 \\
5\end{array}$ & $\begin{array}{l}\text { Leucocytes (44) } \\
\text { Presumably leuc. } \\
\quad(14) \\
\text { Presumably leuc. } \\
\quad(8) \\
\text { Presumably leuc. } \\
\quad(33)\end{array}$ & $\begin{array}{l}\text { Extra fragment in } 11 \text { cells } \\
\text { Extra fragment in } 5 \text { cells } \\
\text { Extra fragment in } 2 \text { cells } \\
\text { Extra fragment in } 3 \text { cells }\end{array}$ & Not reported \\
\hline $\begin{array}{l}\text { Hooft, Lormans, and } \\
\text { Jongbloet (1965) }\end{array}$ & No. 3 & $\mathbf{M}$ & $1 \frac{1}{2}$ & $\begin{array}{l}\text { ? (28) } \\
\text { ? (17) }\end{array}$ & $\left.\begin{array}{l}\text { Short arm of } 13-15 \\
\text { chromosome consistently } \\
\text { showed excess chromosome } \\
\text { material } \\
\text { Short arm of } 21-22 \\
\text { chromosome consistently } \\
\text { showed excess chromosome } \\
\text { material }\end{array}\right\}$ & Not reported \\
\hline $\begin{array}{l}\text { Bishun and Morton } \\
(1965) \\
\text { (Case reported by } \\
\text { Dodge (1965) also) }\end{array}$ & - & $\mathbf{M}$ & Infancy & $\begin{array}{l}\text { Leucocytes (62) } \\
\text { Fibroblasts (15) }\end{array}$ & $\begin{array}{l}\text { Extra fragment in } 17 \text { and } 3 \\
\text { cells from leucocyte and } \\
\text { fibroblast culture, } \\
\text { respectively }\end{array}$ & Not reported \\
\hline $\begin{array}{l}\text { Craig and Luzzatti } \\
\text { (1965) }\end{array}$ & - & $\mathbf{M}$ & 2 & Leucocytes (54) & $\begin{array}{c}\text { Consistent } 2 / 6-12 \\
\text { translocation }\end{array}$ & $\begin{array}{l}\text { Parents and sister-normal } \\
\text { karyotypes }\end{array}$ \\
\hline $\begin{array}{l}\text { Payne and Maeda } \\
\text { (1965) }\end{array}$ & $\begin{array}{l}\text { No. } 1 \\
\text { No. } 2\end{array}$ & $\begin{array}{l}\mathbf{M} \\
\mathbf{M}\end{array}$ & $\begin{array}{l}2 \\
7\end{array}$ & $\begin{array}{l}\text { Leucocytes (17) } \\
\text { Leucocytes (9) }\end{array}$ & $\left.\begin{array}{l}\text { Possible long-arm deletion of } \\
\text { a } 6-12 \text { in } 3 \text { cells } \\
4-5 / 6-12 \text { translocation, plus } \\
\text { fragment in } 6 \text { cells }\end{array}\right\}$ & Not reported \\
\hline $\begin{array}{l}\text { Falek, Schmidt, and } \\
\text { Jervis (1966) }\end{array}$ & No. 1 & $\mathbf{F}$ & 9 & Leucocytes (100) & $\begin{array}{l}\text { Consistent } 3 / 21-22 \\
\text { translocation involving } \\
\text { partial trisomy } 3\end{array}$ & $\begin{array}{c}+a-\text { similar karyotype and } \\
\text { phenotype } \\
b \text { - balanced } 3 / 21-22 \text { trans. } \\
\text { and normal } \\
\text { phenotype } \\
c \text { - normal karyotype and } \\
\text { phenotype }\end{array}$ \\
\hline
\end{tabular}

* Since this paper was written, Cavalieri and Garafalo (1966) reported a boy with de Lange syndrome, with apparent chromatid breaks in some cells in leucocyte culture. In addition, Massimo and Vianello (1965) reported a 5-year-old girl, with some clinical features suggestive of de Lange syndrome, in whom 15 out of 40 cells, in leucocyte culture, showed an extra chromosomal 'fragment'. Each parent had an apparently normal karyotype.

$\dagger a=$ sister and maternal lst cousin $\left(\delta^{*}\right) ; b=$ brother, mother, maternal 1 st cousin ( $\left.\sigma^{*}\right), 2$ maternal uncles, and 2 maternal aunts; $c=$ brother, sister, father, and 2 maternal aunts.

\section{Discussion}

One of the problems with the de Lange syndrome is the absence of any known specific criterion or test which establishes the diagnosis with certainty. Nevertheless, the presence of a characteristic combination of clinical peculiarities, such as was observed in the patient described here, enables a reasonably objective diagnosis of the syndrome to be made.

Chromosomal examination has been undertaken in about half of approximately 150 recorded cases so diagnosed. A minority of these have been reported to show various chromosomal anomalies which are summarized in Table III. Another variant for this list is provided by the present patient. In this family, the metacentric 6-12 group chromosome, noted consistently in the propositus and his phenotypically normal father, could be accounted for by a number of possible chromosomal rearrangements, the simplest of which is a pericentric inversion. However, the morphological similarity of this metacentric chromosome in the father and his son does not necessarily mean that the arrangement of chromosomal material in the two cases is identical, a consideration which de Grouchy, Aussannaire, Brissaud, and Lamy (1966) have discussed.

The finding of an apparently normal karyotype in the large proportion of cytologically examined persons with the de Lange syndrome, together with the inconsistent chromosomal anomalies noted in the remainder, appears to exclude a specific aberration in chromosome morphology, detectable by present techniques, as the aetiological basis for the syndrome. The various chromosomal anomalies noted may, therefore, be coincidental or a possible

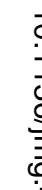


effect, albeit variable, of whatever causal agency (as yet unknown) is producing the phenotypical manifestations of the syndrome. In the absence of further data, there seems to be little merit in speculating beyond this point.

\section{Summary}

The case of a West Indian boy, diagnosed as an instance of de Lange syndrome, is presented. On cytological examination, he and his phenotypically normal father consistently showed an atypical metacentric 6-12 group chromosome, thought to be a No. 9. Chromosomal findings in the de Lange syndrome are briefly reviewed with the conclusion that anomalies in the karyotype, noted in this condition, probably are either coincidental or a variable effect of the unknown causal agency which produces the clinical symptomatology of the syndrome.

We are grateful to Professor L. S. Penrose and Dr. J. Ellis for valuable comments, to Miss Madeleine Pendrey for technical assistance, and to Mr. A. J. Lee for preparing Fig. 3.

\section{REFERENCES}

Bishun, N. P., and Morton, W. R. M. (1965). Brachmann/de Lange syndrome. Lancet, $1,439$.

Cavalieri, S., and Garofalo, E. (1966). Sindrome di Cornelia de Lange in un maschio di 4 anni. Fracastoro, 59, 745.
Craig, A. P., and Luzzatti, L. (1965). Translocation in de Lange's syndrome? Lancet, 2, 445.

Dodge, J. A. (1965). De Lange's Amsterdam dwarfs syndrome: case report. Develop. Med. Child Neurol., 7, 31.

Falek, A., Schmidt, R., and Jervis, G. A. (1966). Familial de Lange syndrome with chromosome abnormalities. Pediatrics, 37, 92.

Ferguson-Smith, M. A., Ferguson-Smith, M. E., Ellis, P. M., and Dickson, M. (1962). The sites and relative frequencies of secondary constrictions in human somatic chromosomes. Cytogenetics, $1,325$.

Ford, C. E. (1964). Autosomal abnormalities. In 2nd Internat. Congr. Congen. Malforms., compiled and edited by International Medical Congress Ltd., New York, p. 28.

Geudeke, M., Bijlsma, J. B., and de Bruijne, J. I. (1963). Chromosomen-onderzoek bij typus degenerativus Amsterodamensis (syndroom van de Lange). Maandschr. Kindergeneesk., 31, 248.

de Grouchy, J., Aussannaire, M., Brissaud, H. E., and Lamy, M (1966). Aneusomie de recombinaison: three further examples. Amer. F. hum. Genet., 18, 467.

Hooft, C., Lormans, J., and Jongbloet, P. (1965). Typus degenerativus Amstelodamensis ou syndrome de Cornelia de Lange. Acta paediat. belg., 19, 5 .

Jervis, G. A., and Stimson, C. W. (1963). De Lange syndrome. 7. Pediat., 63, 634.

de Lange, C. (1933). Sur un type nouveau de dégénération (typus Amstelodamensis). Arch. Méd. Enf., 36, 713.

Massimo, L., and Vianello, M. G. (1965). Syndrome de malformations multiples avec un chromosome supplémentaire chez une petite fille. Ann. paediat. (Basel), 204, 244.

Palmer, C. G., and Funderburk, S. (1965). Secondary constrictions in human chromosomes. Cytogenetics, 4, 261.

Payne, H. W., and Maeda, W. K. (1965). The Cornelia de Lange syndrome: clinical and cytogenetic interpretations. Canad. med. Ass. F., 83, 577.

Ptacek, L. J., Opitz, J. M., Smith, D. W., Gerritsen, T., and Waisman, H. A. (1963). The Cornelia de Lange syndrome. f. Pediat., 63, 1000.

Smith, G. F. (1966). A study of the dermatoglyphs in de Lange syndrome. F. ment. Defic. Res., 10, 241. 